\title{
Nitrogen, phosphorus and potassium mass balances in an irrigated quinoa field
}

\author{
Jorge Alvar-Beltrán, ${ }^{1}$ Marco Napoli, ${ }^{1}$ Abdalla Dao, ${ }^{2}$ Ouattara Amoro, ${ }^{2}$ Leonardo Verdi, ${ }^{1}$ \\ Simone Orlandini, ${ }^{1}$ Anna Dalla Marta ${ }^{1}$ \\ ${ }^{1}$ Department of Agriculture, Food, Environment and Forestry (DAGRI), University of Florence, Florence, \\ Italy; ${ }^{2}$ Institute of Environment and Research in Agriculture (INERA), Bobo Dioulasso, Burkina Faso
}

\section{Highlights}

12.7, 1.6 and $35.5 \mathrm{~kg} \mathrm{ha}^{-1}$ of $\mathrm{N}, P$ and $K$, respectively, are required to produce 1 ton of quinoa biomass.

Seed yields of $1380 \mathrm{~kg} \mathrm{ha}^{-1}$ can be attainded under full irrigation and $100 \mathrm{~kg} \mathrm{ha}^{-1}$ of N.

MAPE values of $-7.5,+4.3$ and +3.3 between $N, P, K$ mass balance calculations and observed values in the field.

\begin{abstract}
Sub-Saharan Africa (SSA) needs to increase food productivity to alleviate food insecurity exacerbated by climate variability and increasing food demand. Balancing macronutrient inputs is essential for sustaining yields, increasing farmer's income and minimizing environmental costs deriving from fertilizer misuse. The present study calculates the nitrogen $(\mathrm{N})$, phosphorus $(\mathrm{P})$ and potassium $(\mathrm{K})$ mass balances and estimates macronutrient inputs and outputs of a quinoa field cultivated under full and deficit irrigation conditions (100 and 50\% crop evapotranspiration - ETc), in either the presence or absence of $\mathrm{N}$ fertilizer (100 and $0 \mathrm{~kg} \mathrm{ha}^{-1}$ of $\mathrm{N}$ ). The emerging findings show that to produce one ton of quinoa
\end{abstract}

Correspondence: Jorge Alvar-Beltrán, Department of Agriculture, Food, Environment and Forestry (DAGRI), University of Florence, Florence, Italy. E-mail: jorge.alvar@unifi.it

Key words: Sub-Saharan Africa; macronutrient budgets; water management; fertilization; sustainable agriculture

Acknowledgements: the authors want to thank Dr. Amoro Ouattara from the Plant, Water and Soil department of INERA's Farako-Ba research station for supporting this research activities with the analysis of soil, plant, and fertilizer samples. Special thanks to the FAO for seed provision necessary for conducting this research.

Conflict of interests: the authors declare no potential conflict of interests.

Received for publication: 16 December 2020.

Revision received: 19 February 2021.

Accepted for publication: 20 February 2021.

${ }^{(C)}$ Copyright: the Author(s), 2021

Licensee PAGEPress, Italy

Italian Journal of Agronomy 2021; 16:1788

doi:10.4081/ija.2021.1788

This article is distributed under the terms of the Creative Commons Attribution Noncommercial License (by-nc 4.0) which permits any noncommercial use, distribution, and reproduction in any medium, provided the original author(s) and source are credited. biomass (including seeds, stems and leaves) $12.7,1.6$ and $35.5 \mathrm{~kg}$ $\mathrm{ha}^{-1}$ of $\mathrm{N}, \mathrm{P}$ and $\mathrm{K}$, respectively, need to be added into the soil. While $\mathrm{N}$ and $\mathrm{K}$ are required at medium to fairly high amounts, $\mathrm{P}$ is needed in lower amounts. Hence, fertilizers in the form of potassium nitrate $\left(\mathrm{KNO}_{3}\right)$ are more suitable than those with higher phosphorus concentrations, for example phosphate $\left(\mathrm{PO}_{4}{ }^{3-}\right)$. Overall, evidences from field experimentations are necessary for integrating farming input recommendations on crop agronomic guidelines, driven by national agricultural research institutions, and for promoting sustainable agriculture in SSA.

\section{Introduction}

The monitoring of macronutrient concentration in the soil is fundamental, providing useful information about soil nutrient deficiencies and surpluses affecting plant development. Information on soil macronutrient content is necessary to support agricultural systems and for better understanding biogeochemical cycles between the soil, plant and atmosphere. Soil fertility dynamics in land use systems are governed by input and output factors known as mass balances. The N, P, K mass balances are used in agricultural systems for determining the environmental performance of agricultural management strategies and nutrient fluxes. Mass balances are also important towards attaining an effective and sustainable management of fertilizers, as application rates in agricultural systems often exceed plant $\mathrm{N}, \mathrm{P}, \mathrm{K}$ requirements (Robertson and Vitousek, 2009). Excessive fertilizer inputs can result in water and air pollution, which in turn can cause eutrophication and acid rain (USEPA, 2004). This generally occurs when applying inorganic fertilizers with a higher macronutrient concentration than organic fertilizers (Sheaffer and Moncada, 2012). For example, most of the $\mathrm{N}$ uptake from urea$\mathrm{CO}\left(\mathrm{NH}_{2}\right)_{2}$ occurs when hydrolysis converts $\mathrm{CO}\left(\mathrm{NH}_{2}\right)_{2}$ into $\mathrm{NH}_{4}{ }^{+}$ and $\mathrm{NO}_{3}{ }^{-}$(IPNI, 2019). However, during this process, $\mathrm{NO}_{3}{ }^{-}$losses (leaching) can happen, as well as $\mathrm{N}_{2} \mathrm{O}$ losses in the form of greenhouse gas emissions (volatilization) from denitrification (IPNI, 2019).

Over the past century, $\mathrm{N}$ has played a key role on world food production and increasing $\mathrm{N}$ applications have been responsible for a 30 to $50 \%$ yield enhancement worldwide (Eickhout et al., 2006; Erisman, 2008). Although at a slower pace than elsewhere, 
cereal production has continued to increase in Sub-Saharan Africa (SSA). During this period, conservation agriculture (e.g. minimum tillage, permanent organic soil cover, crop rotation and intercropping) has been promoted to sustainably manage cropping systems and to enhance agricultural productivity within SSA (FAO, 2011; Vanlauwe et al., 2014). The accomplishment of the previous is the result of a good balance of macronutrients, and to a frequent assessment of crop uptake dynamics and determination of suitable timing for nutrient application (Zingore et al., 2014).

For quinoa (Chenopodium quinoa Willd.), there is a positive relationship between $\mathrm{N}$ application and yield, with a $96 \%$ yield increase between 0 and $120 \mathrm{~kg} \mathrm{ha}^{-1}$ of $\mathrm{N}$ (Kaul et al., 2005). However, the effective physiological use of $\mathrm{N}$ in seed production ( $\mathrm{N}$ use efficiency-NUE- as the ratio of grain yield to $\mathrm{N}$ in the plant) does not decline with increasing $\mathrm{N}$ rates, with an average of 22.2 $\mathrm{kg}$ of seed produced per $\mathrm{kg}$ of $\mathrm{N}$ uptake by aboveground biomass (Kaul et al., 2005). While some studies report yield losses of $24 \%$ when reducing $\mathrm{N}$ rates from 160 to $40 \mathrm{~kg} \mathrm{ha}^{-1}$ of N (Jacobsen et al., 1994), others suggest that quinoa responds differently to $\mathrm{N}$ fertilization depending on the location (Denmark and The Netherlands) as well as from year to year (Moreale et al., 1993). Moreover, different $\mathrm{N}, \mathrm{P}$ and $\mathrm{K}$ concentrations are required for either seed or aerial biomass production. Quinoa seeds are of interest giving its nutritional properties, where biomass is used for feeding ruminants and non-ruminating animals (Blanco, 2016). For instance, Moreale et al. (1993) report an average demand of 18.8, 5.0 and $13.8 \mathrm{~kg}$ of $\mathrm{N}, \mathrm{P}$ and $\mathrm{K}$, respectively, per ton of seed produced; whereas biomass requires on average $5.0,1.8$ and $32.5 \mathrm{~kg}$ of N, P and $\mathrm{K}$, respectively, per ton of stems and leaves produced. Additional studies suggest that $\mathrm{P}$ and $\mathrm{K}$ content in quinoa seeds is higher to that of other grains (4570 mg kg-1 of $\mathrm{P}$ and $5630 \mathrm{mg} \mathrm{kg}^{-1}$ of $\mathrm{K}$ ), and silage analysis show $\mathrm{P}$ seed concentrations of $0.22 \%$ (USDA, 2013; Blanco, 2016). Unlike N, the amount of research assessing the effect of increasing $\mathrm{P}$ and $\mathrm{K}$ rates on quinoa growth is still limited. Some studies affirm that $80 \mathrm{~kg} \mathrm{ha}^{-1}$ of $\mathrm{P}_{2} \mathrm{O}_{5}$ and $100 \mathrm{~kg} \mathrm{ha}^{-1}$ of $\mathrm{K}_{2} \mathrm{O}$ are the optimal $\mathrm{P}$ and $\mathrm{K}$ concentrations for producing two tons of seed in tropical environments (Spehar, 2015). Instead, the $\mathrm{N}$ supply in these environments is recommended at $20-30 \mathrm{~kg} \mathrm{ha}^{-1}$ of $\mathrm{N}$ at sowing, and $40-50 \mathrm{~kg} \mathrm{ha}^{-1}$ of $\mathrm{N}$ at $30-50$ days after sowing (DAS) (Spehar, 2010). However, the timing of fertilization in the Sahel varies according to the sowing date and genotype in study (Alvar-Beltrán et al., 2019; Dao et al., 2020).

Given that N plays a key role on plant growth and crop yield, and the limited literature on $\mathrm{N}, \mathrm{P}, \mathrm{K}$ removal by quinoa from different levels of water supply and $\mathrm{N}$ fertilization, the present study promotes sustainable agriculture in SSA by estimating N, P, K content in quinoa seeds and aerial biomass. Our study uses a simple mass balance approach to calculate the removal of N, P, K by seeds and biomass, and investigates the combined effect of water and $\mathrm{N}$ fertilizer on crop growth and development. Therefore, by conducting a comprehensive study on the N, P, K mass balances and surpluses from fertilizer application farming systems in SSA are improved. To conclude, both the drawbacks and recommendations on soil-plant nutrient dynamics, from fertilizer applications under different irrigation schedules, are a useful source of information for national agricultural research institutions.

\section{Materials and methods}

\section{Site description}

This experiment was conducted during the dry season, from 25 October 2018 to 17 January 2019 (sowing and harvesting dates, respectively), at Institut de l'Environnement et de Recherches Agricoles (INERA) Farako-Bâ research station $\left(11^{\circ} 05^{\prime} \mathrm{N}\right.$ and $4^{\circ}$ $20^{\prime} \mathrm{W} ; 405$ m.a.s.1.), Burkina Faso. The agroclimatic conditions of the experimental site were characterized by a tropical savannah (wet and hot) climate. Although the rainy season lasts from May to October, with a total amount of rainfall exceeding $900 \mathrm{~mm}_{\text {year }}{ }^{-1}$ and an average annual temperature of $28^{\circ} \mathrm{C}$, the total precipitation observed during the present experiment (October-January corresponding to the dry season) was $8.1 \mathrm{~mm}$ and an average temperature of $26.2^{\circ} \mathrm{C}$. Meteorological information was retrieved from a weather station belonging to the National Hydro-Meteorological Service (ANAM) and placed within INERA's research station (Figure 1).

\section{Experimental set-up and irrigation system}

This research was performed using a randomized split-block experimental design, with a multiple factor analysis of variance (ANOVA) as follows: two levels of irrigation according to the estimated ETc (full irrigation, FI: 100\% ETc; deficit irrigation, DI: $50 \% \mathrm{ETc})$ and two levels of $\mathrm{N}$ fertilization (100 and $0 \mathrm{~kg} \mathrm{ha}^{-1}$ of $\mathrm{N}$, hereafter $\mathrm{N} 1$ and $\mathrm{N} 0$, respectively) each with four replicates (Figure 2). In total, 16 plots sizing $12.5 \mathrm{~m}^{2}$, with a $0.50 \mathrm{~m}$ distance between rows and $0.10 \mathrm{~m}$ space between plants. The selected quinoa genotype, cv. Titicaca, was characterized by a short growing cycle (85 days). The field was irrigated using a drip-irrigation system and the amount of irrigation was measured using a water counter placed at the entry of each irrigation block (FI and DI). The daily ET was calculated using Hargreaves \& Samani's (1985) equation and computed as follows:

$$
E T_{o}=0.0023 \frac{R_{o}}{\lambda}\left(T_{\text {mean }}+17.8\right)\left(T_{\text {max }}-T_{\text {min }}\right)^{0.5}
$$

where: $R_{o}=$ extra-terrestrial solar radiation $\left(1 \mathrm{MJ} \mathrm{m}^{-2}\right.$ day $\left.^{-1}\right)$ at a given month and latitude (Allen et al., 1998); $\lambda=$ latent heat of water vaporization at $20^{\circ} \mathrm{C}\left(2.45 \mathrm{MJ} \mathrm{kg}^{-1}\right)$, changing the extra-terrestrial radiation units into $\mathrm{mm}$ day $^{-1}$ of evaporation; $T$ mean = mean daily temperature $\left({ }^{\circ} \mathrm{C}\right) ; \operatorname{T~} \max =$ daily maximum temperature $\left({ }^{\circ} \mathrm{C}\right) ; T$ min $=$ daily minimum temperature $\left({ }^{\circ} \mathrm{C}\right)$.

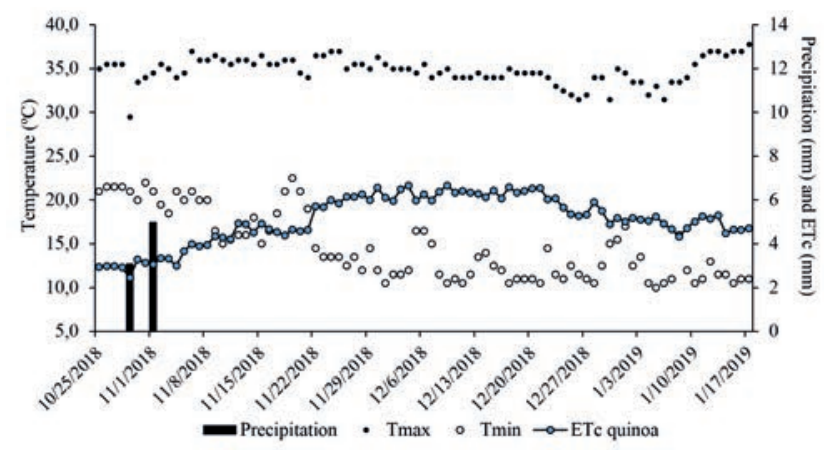

Figure 1. Observed maximum and minimum temperatures $\left({ }^{\circ} \mathrm{C}\right)$, precipitation $(\mathrm{mm})$ and estimated crop evapotranspiration (ETc in $\mathrm{mm}$ ) during the growing season $(25 / 10 / 2018$ to $17 / 01 / 2019)$. 


\section{Agronomic practices}

A handheld mechanical plough $(0.20 \mathrm{~m}$ depth) was used during field preparation. Afterwards, the experimental field was equally amended with $5000 \mathrm{~kg} \mathrm{ha}^{-1}$ of compost and fertilized with $400 \mathrm{~kg}$ $\mathrm{ha}^{-1}$ of Burkina phosphate rock (BPR) $(26.8 \%$ phosphoric anhydride, $\left.\mathrm{P}_{2} \mathrm{O}_{5}\right)$ (Table 1). To determine the N, $\mathrm{P}$ and $\mathrm{K}$ concentrations, three and 16 soil samples were collected before sowing and after harvesting, respectively, at both $0-0.20 \mathrm{~m}$ and $0.20-0.40 \mathrm{~m}$ depth (Figure 2). These samples were collected before sowing and linearly interpolated to estimate the physic-chemical properties of the soil for all 16 plots. The $\mathrm{N}$ fertilization was performed twice (at 15 and 30 DAS) by broadcasting urea $(46.2 \% \mathrm{~N})$ at a rate of $217 \mathrm{~kg}$ $\mathrm{ha}^{-1}$, corresponding to a total of $100 \mathrm{~kg} \mathrm{ha}^{-1}$ of N (N1). The total amount of $\mathrm{N}$ applied during the growing cycle was equivalent to
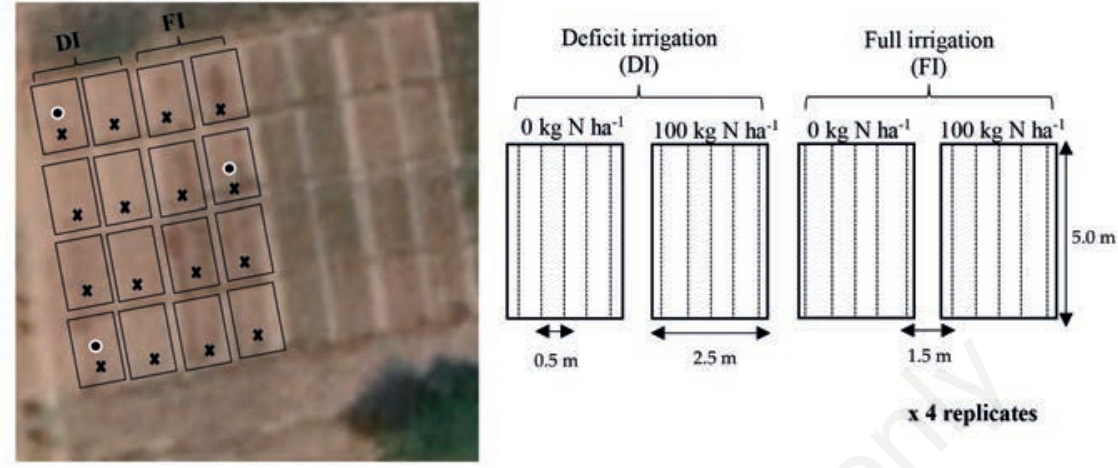

$x 4$ replicates

Figure 2. Satellite image (left) showing the experimental field and location of soil samples (o) prior to sowing and plant/soil (x) samples at harvest, as well as the experimental design (right).

Table 1. Chemical characteristics of the different fertilizers used during the experimentation: compost, urea $\left(\mathrm{CO}\left(\mathrm{NH}_{2}\right)_{2}\right)$ and $\mathrm{Burkina}$ phosphate rock (BPR).

\begin{tabular}{|c|c|c|c|c|}
\hline Parameter & Units & Compost & Urea & Phosphate rock \\
\hline $\mathrm{pH}\left(\mathrm{H}_{20}\right)$ & - & 7.3 & - & - \\
\hline $\mathrm{C}$ & $\%$ & 29.1 & - & - \\
\hline Organic matter & $\%$ & 50.2 & - & - \\
\hline $\mathrm{N}$ & $\%$ & 1.1 & 46.2 & - \\
\hline $\mathrm{C} / \mathrm{N}$ & - & 27 & - & - \\
\hline P total & $\%$ & 0.2 & - & 11.7 \\
\hline K total & $\%$ & 2.4 & - & - \\
\hline Ca total & $\%$ & 1.4 & - & - \\
\hline
\end{tabular}

Table 2. Average physic-chemical characteristics of the soil at different depths $(0-0.20$ and $0.20-0.40 \mathrm{~m})$ before sowing (average of three samples) and after harvesting (average of 16 samples).

\begin{tabular}{|c|c|c|c|c|c|}
\hline \multirow[b]{2}{*}{ Parameter } & \multirow[b]{2}{*}{ Units } & \multicolumn{2}{|c|}{ Before sowing } & \multicolumn{2}{|c|}{ After harvesting } \\
\hline & & $0-0.20 \mathrm{~m}$ & $0.20-0.40 \mathrm{~m}$ & $0-0.20 \mathrm{~m}$ & $0.20-0.40 \mathrm{~m}$ \\
\hline Sand & $\%$ & 75.1 & 58.3 & - & - \\
\hline Silt & $\%$ & 14.2 & 12.4 & - & - \\
\hline Clay & $\%$ & 10.7 & 29.3 & - & - \\
\hline Texture & & Loamy-Sandy & Sandy-Clay-Loam & - & - \\
\hline $\mathrm{pH}\left(\mathrm{H}_{2} \mathrm{O}\right)$ & & 6.3 & 6.3 & 6.7 & 6.7 \\
\hline $\mathrm{C}$ & $\mathrm{kg} \mathrm{ha}^{-1}$ & 7788.0 & 6634.6 & 8986.3 & 7200.3 \\
\hline Organic matter & $\mathrm{kg} \mathrm{ha}^{-1}$ & 13426.5 & 11438.0 & 15492.3 & 12413.4 \\
\hline $\mathrm{N}$ total & $\mathrm{kg} \mathrm{ha}^{-1}$ & 814.2 & 621.9 & 826.3 & 659.0 \\
\hline $\mathrm{C} / \mathrm{N}$ & & 9.7 & 10.7 & 10.9 & 11.0 \\
\hline P total & $\mathrm{kg} \mathrm{ha}^{-1}$ & 472.8 & 365.1 & 545.8 & 460.4 \\
\hline $\mathrm{P}_{\text {Bray 1 }}$ & $\mathrm{kg} \mathrm{ha}^{-1}$ & 84.6 & 51.6 & 85.6 & 60.2 \\
\hline K total & $\mathrm{kg} \mathrm{ha}^{-1}$ & 1427.7 & 2834.9 & 1542.5 & 2778.1 \\
\hline K available & $\mathrm{kg} \mathrm{ha}^{-1}$ & 220.1 & 324.5 & 322.5 & 178.9 \\
\hline Bulk density & $\mathrm{kg} \mathrm{m}^{-3}$ & 1120 & - & - & - \\
\hline
\end{tabular}


$54.5 \mathrm{~kg} \mathrm{ha}^{-1}$ of $\mathrm{N}$ (from compost in non-N fertilized treatments) and $154.5 \mathrm{~kg} \mathrm{ha}^{-1}$ of $\mathrm{N}$ (from $\mathrm{CO}\left(\mathrm{NH}_{2}\right)_{2}$ and compost in $\mathrm{N}$-fertilized treatments). The total $\mathrm{P}$ and $\mathrm{K}$ application before sowing was $56.1 \mathrm{~kg} \mathrm{ha}^{-1}$ of P (46.7 kg ha $\mathrm{k}^{-1}$ of P from BPR and $9.6 \mathrm{~kg} \mathrm{ha}^{-1}$ of $\mathrm{P}$ from compost) and $111.7 \mathrm{~kg} \mathrm{ha}^{-1}$ of $\mathrm{K}$ from compost, respectively. To calculate the total amount of carbon (C), N, P and K content in the top-soil layer $(0-0.20 \mathrm{~m})$, the bulk density was measured $\left(1.12 \mathrm{t} \mathrm{m}^{-3}\right)$ and estimated at $2240 \mathrm{t} \mathrm{ha}^{-1}$ (Table 2).

\section{Nitrogen, phosphorus and potassium mass balances and surpluses}

The removal of N, P and K per experimental plot was calculated using 12 seed samples and three stem and leaf samples. The entire $\mathrm{N}$ cycle, including values of atmospheric $\mathrm{N}$ deposition (wet and dry) and $\mathrm{N}$ emissions, was determined using the data provided by Delon et al. (2010). The latter experiment was conducted under similar agroclimatic conditions to those of this study (KatibougouMali at $12^{\circ} 54^{\prime} \mathrm{N}$ and $7^{\circ} 31^{\prime} \mathrm{W} ; 307$ m.a.s.1). The amount of $\mathrm{N}$ deposition (both wet and dry) between November-January was estimated at $2.8 \mathrm{~kg} \mathrm{ha}^{-1}$ of $\mathrm{N}$ and the $\mathrm{N}$ emissions at $9.7 \mathrm{~kg} \mathrm{ha}^{-1}$ of $\mathrm{N}$. As our experiment was conducted during the dry season using a drip-irrigation system, losses from leaching were not considered.

The gross $\mathrm{N}$ balance (NB) was computed as follows:

$N B=\left(N_{\text {soil before sowing }}+N_{\text {urea }}+N_{\text {compost }}+N_{\text {atmospheric deposition (wet \& dry) }}\right)-$ $\left(N_{\text {uptake plant }}+N_{\text {uptake seeds }}+N_{\text {soil emissions }}\right)$

The gross $\mathrm{P}$ balance (PB) was computed as follows:

$P B=\left(P_{\text {soil before sowing }}+P_{\text {phosphate }}+P_{\text {compost }}\right)-\left(P_{\text {uptake plant }}+P_{\text {uptake seeds }}\right)$

The gross $\mathrm{K}$ balance $(\mathrm{KB})$ was computed as follows:

$K B=\left(K_{\text {soil before sowing }}+K_{\text {phosphate }}+K_{\text {compost }}\right)-\left(K_{\text {uptake plant }}+K_{\text {uptake seeds }}\right)$

The N surplus (NS) was computed as follows:

$N S=\left(N_{\text {urea }}+N_{\text {compost }}+N_{\text {atmospheric deposition (wet \& dry) }}\right)-\left(N_{\text {uptake plant }}+\right.$ $N_{\text {uptake seed) }}$

The P surplus (PS) was computed as follows:

$P S=\left(P_{\text {phosphate }}+P_{\text {compost }}\right)-\left(P_{\text {uptake plant }}+P_{\text {uptake seeds }}\right)$

The $\mathrm{K}$ surplus $(\mathrm{KB})$ was computed as follows:

$K S=\left(K_{\text {phosphate }}+K_{\text {compost }}\right)-\left(K_{\text {uptake plant }}+K_{\text {uptake seeds }}\right)$

The N, P, K requirements per one ton of seeds and one ton of stems and leaves were computed as follows (as reported by Gebrelibanos and Dereje, 2015):

$$
\text { N uptake }=\frac{\text { Seed yield }\left(\frac{\mathrm{kg}}{\mathrm{ha}}\right) \times \text { Seed total } \mathrm{N}\left(\frac{\mathrm{kg}}{\mathrm{ha}}\right)}{100}
$$

The total N, P, K requirements per one ton of total dry biomass (seeds, stems and leaves) was calculated from the harvest index (HI) as follows:

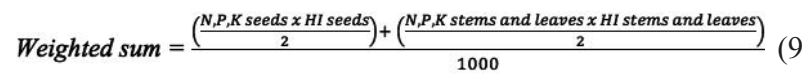

\section{Statistical analysis}

Data were examined by analysis of variance (ANOVA) and by pairwise comparison of means using the Tukey HSD test with critical value $P<0.05$. All the statistics were conducted using the $R$ software (version 5.3.3). To estimate the differences between observed and simulated values, the mean absolute percentage error (MAPE) was used and computed as follows:

$M A P E=\frac{1}{N} \sum_{i=1}^{i=N} \frac{|O i-P i|}{(O i)} x 100$

Where: $\mathrm{O}_{\mathrm{i}}$ is the observed value, $P_{i}$ is the simulated value.

\section{Results}

\section{Physic-chemical characteristics of the experimental site}

The experimental field was characterized for having a loamsandy texture at $0-0.20 \mathrm{~m}$, and a sandy-clay-loam texture at 0.20 $0.40 \mathrm{~m}$, respectively (Table 2 ). The total amount of $\mathrm{N}$ found in the top layer was 814.2 and $826.3 \mathrm{~kg} \mathrm{ha}^{-1}$ before sowing and after harvesting, respectively. The total amount of organic matter (OM), C, $\mathrm{P}$ and $\mathrm{K}$ found in the soil at sowing was significantly lower to that observed at harvest (Table 2). The reported increase in OM, C, P, $\mathrm{K}$, and, to a lesser extent, of $\mathrm{N}$ between sowing and harvesting was due to compost (5000 $\left.\mathrm{kg} \mathrm{ha}^{-1}\right)$, urea $\left(100 \mathrm{~kg} \mathrm{ha}^{-1}\right.$ of $\left.\mathrm{N}\right)$ and BPR

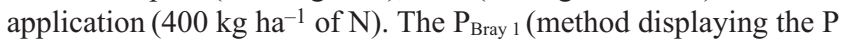
availability in the soil) and $\mathrm{K}$ availability at $0-0.20 \mathrm{~m}$ was 84.6 and $85.6 \mathrm{~kg} \mathrm{ha}^{-1}$ of $\mathrm{P}$ and 220.1 and $322.5 \mathrm{~kg} \mathrm{ha}^{-1}$ of $\mathrm{K}$ before sowing and after harvesting, respectively.

\section{Nitrogen, phosphorus and potassium uptake}

The ANOVA and Tukey HSD post-hoc test for N, P, K uptake showed significant differences between treatments and for different parts of the plant (Table 3 ). $\mathrm{N}$ was the macronutrient of greatest interest, as $\mathrm{P}$ and $\mathrm{K}$ fertilization was only provided at the time of sowing and not throughout the experiment as in the case of N. For the treatment FI-N1, the total N uptake (seeds, stems and leaves) was of $50.6 \mathrm{~kg} \mathrm{ha}^{-1}$ of $\mathrm{N}$, and for the opposite treatment, DI-N0, $10.2 \mathrm{~kg} \mathrm{ha}^{-1}$ of $\mathrm{N}$ (Table 3). The main effect between factors showed that quinoa was more reactive to irrigation than to $\mathrm{N}$ fertilization. However, for both factors significant differences were reported $(\mathrm{P}<0.05)$. Differences in the response of plants to $\mathrm{N}$ fertilization and irrigation was reflected in the dry biomass at harvest (seeds, stems and leaves). For instance, the seed yields from the FI-N1 treatment were significantly $(\mathrm{P}<0.05)$ higher than those found in DI-N0 (Table 3). Although significant differences were observed when irrigation and $\mathrm{N}$ fertilization acted as a main factor effect, larger differences in terms of yield were reported between irrigation treatments (1127.7 and $276.3 \mathrm{~kg} \mathrm{ha}^{-1}$ of seed under FI and DI, respectively) when compared to $\mathrm{N}$ fertilization treatments (838.5 and $565.4 \mathrm{~kg} \mathrm{ha}^{-1}$ of $\mathrm{N}$ under N1 and N0, respectively).

Furthermore, statistical differences $(\mathrm{P}<0.05)$ were also depicted when testing the ANOVA for $\mathrm{P}$ and $\mathrm{K}$. The total $\mathrm{P}$ uptake was strongly influenced by changes in irrigation and $\mathrm{N}$ fertilization, with a positive relationship between higher water inputs and 
increasing $\mathrm{N}$ fertilization rates (FI-N1). For instance, for the FI-N1 treatment the total $\mathrm{P}$ uptake was of $6.3 \mathrm{~kg} \mathrm{ha}^{-1}$ of $\mathrm{P}$; whereas for the treatment DI-N0, the P uptake was as low as $1.2 \mathrm{~kg} \mathrm{ha}^{-1}$ of $\mathrm{P}$ (Table 3). For $\mathrm{P}$, both irrigation and $\mathrm{N}$ fertilization had a similar main effect on total $\mathrm{P}$ uptake, displaying significant differences $(\mathrm{P}<0.05)$ in both cases. Nonetheless, greater differences $(\mathrm{P}<0.05)$ were observed under FI, with a $\mathrm{P}$ uptake of $4.8 \mathrm{~kg} \mathrm{ha}^{-1}$ of $\mathrm{P}$ than under DI, $1.4 \mathrm{~kg} \mathrm{ha}^{-1}$ of P. A similar trend was reported for total $\mathrm{K}$ uptake of seeds, stems and leaves, with a positive relationship between higher irrigation and increasing $\mathrm{N}$ fertilization. As for $\mathrm{P}$, total $\mathrm{K}$ uptake was also significantly higher under the FI-N1 treatment $(\mathrm{P}<0.05)$ than for the DI-N0 treatment (Table 3). However, no significant differences were noted when DI interacted either with N1 and N0, or between FI-N0. Regarding the effect of main factors, the largest differences $(\mathrm{P}<0.05)$ on total $\mathrm{K}$ uptake were displayed under irrigation (total $\mathrm{K}$ uptake of 99.7 and $42.4 \mathrm{~kg} \mathrm{ha}^{-1}$ of $\mathrm{K}$ for FI and DI, respectively) when compared to $\mathrm{N}$ fertilization (total $\mathrm{K}$ uptake of 91.0 and $51.1 \mathrm{~kg} \mathrm{ha}^{-1}$ of $\mathrm{K}$ for $\mathrm{N} 1$ and $\mathrm{N} 0$, respectively).

The total amount of N, P and $\mathrm{K}$ requirements was calculated to assess the macronutrient uptake by the plant per unit of biomass (Eq. 8-9, Table 4). The N requirements were of 20.4 and $7.6 \mathrm{~kg} \mathrm{ha}^{-1}$ of
$\mathrm{N}$ per ton of seeds and per ton of stems and leaves produced, respectively. Additionally, the total amount of $\mathrm{N}$ required to produce one ton of total dry biomass was of $12.7 \mathrm{~kg}$ of $\mathrm{N}$ (weighted sum of seeds, stems and leaves). In addition, in order to produce one ton of seeds and one ton of stems and leaves, the $\mathrm{K}$ requirements were of 16.0 and $42.9 \mathrm{~kg}$ of $\mathrm{K}$, respectively. These findings implied that for producing one ton of total dry biomass, quinoa required a total amount of $35.5 \mathrm{~kg} \mathrm{ha}^{-1}$ of $\mathrm{K}$ (weighted sum of seeds, stems and leaves). Of all macronutrients in study, quinoa demonstrated a lower requirement of $\mathrm{P}$. In order to produce one ton of seeds and one ton of stems and leaves, the $P$ requirements were of 2.8 and $0.8 \mathrm{~kg} \mathrm{ha}^{-1}$ of $\mathrm{P}$, respectively. Overall, quinoa required $1.6 \mathrm{~kg} \mathrm{ha}^{-1}$ of $\mathrm{P}$ (weighted sum of seeds, stems and leaves) to produce one ton of total dry biomass.

\section{Nitrogen, phosphorus and potassium mass balances and surpluses in the soil at harvest}

The effect of the different management strategies, including quinoa genotype, fertilization and irrigation, was evaluated using the N, P and K mass balances (Eq. 2-4) as well as through macronutrient surpluses (Eq. 5-7) found in the soil at harvest (Table 5). In general, much of the differences in mass balances

Table 3. ANOVA Tukey HSD post-hoc test for $\mathrm{N}, \mathrm{P}$ and $\mathrm{K}$ uptake $\left(\mathrm{kg} \mathrm{ha}^{-1}\right)$ for different irrigation schedules $(100$ and $50 \% \mathrm{ETc})$ and $\mathrm{N}$ fertilization levels $\left(100\right.$ and $\left.0 \mathrm{~kg} \mathrm{~N} \mathrm{ha}^{-1}\right)$.

\begin{tabular}{|c|c|c|c|c|c|c|c|c|c|c|c|}
\hline \multirow{2}{*}{$\begin{array}{l}\text { Treatment } \\
\text { IrrigationNitrogen }\end{array}$} & \multicolumn{3}{|c|}{ Nitrogen (N) $\left(\mathrm{kg} \mathrm{ha}^{-1}\right)$} & \multicolumn{3}{|c|}{ Phosphorus (P) $\left(\mathrm{kg} \mathrm{ha}^{-1}\right)$} & \multicolumn{3}{|c|}{ Potassium (K) $\left(\mathrm{kg} \mathrm{ha}^{-1}\right)$} & \multicolumn{2}{|c|}{ Dry biomass (kg ha-1) } \\
\hline & $\begin{array}{l}\text { Seed } \\
\text { uptake }\end{array}$ & $\begin{array}{l}\text { Stem and } \\
\text { leaf } \\
\text { uptake }\end{array}$ & $\begin{array}{l}\text { Total } \\
\text { uptake }\end{array}$ & $\begin{array}{l}\text { Seed } \\
\text { uptake }\end{array}$ & $\begin{array}{c}\text { Stem and } \\
\text { leaf } \\
\text { uptake }\end{array}$ & $\begin{array}{l}\text { Total } \\
\text { uptake }\end{array}$ & $\begin{array}{l}\text { Seed } \\
\text { uptake }\end{array}$ & $\begin{array}{c}\text { Stem and } \\
\text { leaf } \\
\text { uptake }\end{array}$ & $\begin{array}{l}\text { Total } \\
\text { uptake }\end{array}$ & Yield & $\begin{array}{l}\text { Stems } \\
\text { and leaves }\end{array}$ \\
\hline $\mathrm{N} 1$ & $29.0 \pm 4.0^{\mathrm{a}}$ & $21.6 \pm 12.3^{\mathrm{a}}$ & $50.6 \pm 12.8^{\mathrm{a}}$ & $3.9 \pm 0.9^{\mathrm{a}}$ & $2.3 \pm 1.3^{\mathrm{a}}$ & $6.3 \pm 1.8^{\mathrm{a}}$ & $20.6 \pm 3.7^{\mathrm{a}}$ & $112.7 \pm 70.7^{\mathrm{a}}$ & $133.3 \pm 72.0^{\mathrm{a}}$ & $1380.0 \pm 251.4^{\mathrm{a}}$ & $3096.7 \pm 1893.6^{\mathrm{a}}$ \\
\hline $\mathrm{N} 1$ & $6.1 \pm 4.0 c$ & $7.7 \pm 4.2^{b}$ & $13.9 \pm 5.9 c$ & $0.8 \pm 0.6^{c}$ & $0.8 \pm 0.3^{b}$ & $1.7 \pm 0.4 \mathrm{cc}$ & $4.8 \pm 2.7^{c}$ & $43.9 \pm 24.8^{b}$ & $48.7 \pm 25.7^{b}$ & $297.1 \pm 207.2^{c}$ & $982.9 \pm 632.8^{b}$ \\
\hline NO & $18.1 \pm 2.9^{\mathrm{b}}$ & $9.1 \pm 1.0^{b}$ & $27.2 \pm 3.0^{\mathrm{b}}$ & $2.4 \pm 0.3^{b}$ & $1.0 \pm 0.3^{b}$ & $3.4 \pm 0.1^{\mathrm{b}}$ & $13.8 \pm 3.3^{\mathrm{b}}$ & $52.3 \pm 10.5^{b}$ & $66.1 \pm 12.6^{b}$ & $875.4 \pm 98.6^{\mathrm{b}}$ & $1129.6 \pm 79.2^{\mathrm{b}}$ \\
\hline No & $4.9 \pm 2.8^{c}$ & $5.3 \pm 1.5^{b}$ & $10.2 \pm 4.2^{c}$ & $0.7 \pm 0.4^{c}$ & $0.5 \pm 0.2^{b}$ & $1.2 \pm 0.6^{\mathrm{c}}$ & $4.3 \pm 2.8^{c}$ & $31.9 \pm 12.1^{\mathrm{b}}$ & $36.2 \pm 149^{b}$ & $255.4 \pm 153.3^{c}$ & $717.9 \pm 186.5^{b}$ \\
\hline \multicolumn{12}{|c|}{ Main effect: Nitrogen } \\
\hline $\mathrm{N} 1$ & $17.6 \pm 12.1^{\mathrm{a}}$ & $14.7 \pm 11.5$ & $32.3 \pm 20.9 \mathrm{a}$ & $2.4 \pm 1.7$ & $1.6 \pm 1.2$ & $4.0 \pm 2.7^{\mathrm{a}}$ & $12.7 \pm 8.5^{\mathrm{a}}$ & $78.3 \pm 63.2$ & $91.0 \pm 68.6$ & $838.5 \pm 588.4^{\mathrm{a}}$ & $2039.8 \pm 1763.5$ \\
\hline N0 & $11.5 \pm 7.2^{\mathrm{b}}$ & $7.2 \pm 2.3$ & $18.7 \pm 9.3^{b}$ & $1.6 \pm 0.9$ & $0.7 \pm 0.3$ & $2.3 \pm 1.1^{\mathrm{b}}$ & $9.0 \pm 5.6^{b}$ & $42.1 \pm 15.3$ & $51.1 \pm 20.3$ & $565.4 \pm 335.7^{\mathrm{b}}$ & $923.8 \pm 250.8$ \\
\hline \multicolumn{12}{|c|}{ Main effect: Irrigation } \\
\hline $\mathrm{FI}$ & $23.5 \pm 6.5^{\mathrm{a}}$ & $15.4 \pm 10.7^{\mathrm{a}}$ & $38.9 \pm 15.0^{\mathrm{a}}$ & $3.2 \pm 1.0^{\mathrm{a}}$ & $1.7 \pm 1.2^{\mathrm{a}}$ & $4.8 \pm 1.9^{\mathrm{a}}$ & $17.2 \pm 4.9^{\mathrm{a}}$ & $82.5 \pm 58.9^{\mathrm{a}}$ & $99.7 \pm 61.6^{\mathrm{a}}$ & $1127.7 \pm 316.4^{\mathrm{a}}$ & $2113.1 \pm 1662.3^{\mathrm{a}}$ \\
\hline DI & $5.5 \pm 3.5^{b}$ & $6.5 \pm 3.4^{b}$ & $12.0 \pm 5.4^{\mathrm{b}}$ & $0.8 \pm 0.5^{b}$ & $0.7 \pm 0.3^{b}$ & $1.4 \pm 0.5^{b}$ & $4.6 \pm 2.8^{b}$ & $37.9 \pm 20.4^{\mathrm{b}}$ & $42.4 \pm 22.0^{b}$ & $276.3 \pm 183.4^{\mathrm{b}}$ & $850.4 \pm 484.9^{b}$ \\
\hline
\end{tabular}

${ }^{a-c}$ Means that do not share a letter were significant different at $5 \%$ probability level using Tukey HSD post-hoc test.

Table 4. N, P and $\mathrm{K}\left(\mathrm{kg} \mathrm{ha}^{-1}\right)$ requirements to produce one ton of quinoa seeds, one ton of aboveground biomass (stems and leaves) and sum of dry biomass (seeds, stems and leaves) for different irrigation schedules (100 and $50 \% \mathrm{ETc})$ and $\mathrm{N}$ fertilization levels (100 and $0 \mathrm{~kg} \mathrm{ha}^{-1}$ of $\left.\mathrm{N}\right)$.

\begin{tabular}{|c|c|c|c|c|c|c|c|c|c|c|c|c|}
\hline \multicolumn{2}{|c|}{$\begin{array}{l}\text { Treatment } \\
\text { Irrigation Fertilizer }\end{array}$} & \multirow{2}{*}{$\begin{array}{c}\mathrm{N} \\
1.0 \pm 2.9\end{array}$} & $\begin{array}{l}\text { Seeds } \\
\text { P }\end{array}$ & $\mathrm{K}$ & \multicolumn{3}{|c|}{ Stems and leaves } & $\begin{array}{l}\text { Harvest } \\
\text { index of } \\
\text { (seeds) } \\
\%\end{array}$ & $\begin{array}{l}\text { Harvest } \\
\text { index of } \\
\text { stems and } \\
\text { leaves } \\
\%\end{array}$ & \multicolumn{3}{|c|}{$\begin{array}{l}\text { Total requirements } \\
\text { to produce one ton of } \\
\text { seeds, stems } \\
\text { and leaves } \\
\mathrm{N} \quad \mathrm{P}\end{array}$} \\
\hline $\mathrm{FI}$ & $\mathrm{N} 1$ & & $2.9 \pm 0.6$ & $14.9 \pm 2.7$ & $7.0 \pm 4.0$ & $0.8 \pm 0.4$ & $36.4 \pm 22.8$ & 30.8 & 69.2 & 25.3 & 3.1 & 66.7 \\
\hline DI & $\mathrm{N1}$ & $20.7 \pm 13.6$ & $2.8 \pm 1.9$ & $16.2 \pm 9.1$ & $7.9 \pm 4.3$ & $0.8 \pm 1.0$ & $44.6 \pm 25.2$ & 43.7 & 56.3 & 13.6 & 1.7 & 33.0 \\
\hline FI & No & $20.7 \pm 3.3$ & $2.7 \pm 0.3$ & $15.7 \pm 3.7$ & $8.1 \pm 0.8$ & $0.9 \pm 0.3$ & $46.3 \pm 9.3$ & 23.2 & 76.8 & 6.9 & 0.8 & 24.3 \\
\hline \multirow[t]{2}{*}{ DI } & NO & $19.1 \pm 11.0$ & $2.9 \pm 1.8$ & $16.9 \pm 11.0$ & $7.4 \pm 2.1$ & $0.7 \pm 0.2$ & $44.4 \pm 16.9$ & 26.2 & 73.8 & 5.1 & 0.6 & 18.1 \\
\hline & Mean & $20.4 \pm 0.8$ & $2.8 \pm 0.1$ & $16.0 \pm 0.7$ & $7.6 \pm 0.4$ & $0.8 \pm 0.1$ & $42.9 \pm 3.8$ & - & - & 12.7 & 1.6 & 35.5 \\
\hline
\end{tabular}


were displayed for $\mathrm{K}$, implying that $\mathrm{K}$ was more influenced by irrigation and $\mathrm{N}$ fertilization than when compared to $\mathrm{N}$ and $\mathrm{P}$. In regards to the $\mathrm{K}$ mass balance $(\mathrm{KB})$, there was a negative relationship $(\mathrm{P}<0.05)$ with lower and higher values under the FI-N1 and DI-N0 treatments, respectively. However, no significant differences were reported when $\mathrm{N}$ fertilization nor irrigation were the main factor effect. Additionally, K surpluses (KS) showed a similar behaviour to that of $\mathrm{KB}$, with negative surpluses under the FI-N1 treatment $(\mathrm{P}<0.05)$. This was explained by the fact that quinoa required more $\mathrm{K}\left(133.3 \mathrm{~kg} \mathrm{ha}^{-1}\right.$ of $\mathrm{K}$ under FI-N1 as reported in Table 3 ) to that provided by compost (111.7 $\mathrm{kg} \mathrm{ha}^{-1}$ of $\left.\mathrm{K}\right)$. These results confirmed that quinoa removed $\mathrm{K}$ previously found in the soil, and therefore mass balances were negative. The opposite trend occurred for the DI-N0 treatments, with a K surplus of 81.5 $\mathrm{kg} \mathrm{ha}^{-1}(\mathrm{P}<0.05)$. These values were in harmony to those reported in Table 3, where $\mathrm{K}$ uptake (36.2 $\mathrm{kg} \mathrm{ha}^{-1}$ of $\mathrm{K}$ ) was lower under DI-N0.

For the $\mathrm{N}$ mass balance (NB), no significant differences $(\mathrm{P}>0.05)$ were described for the interactions between irrigation and $\mathrm{N}$ fertilization. Even though the highest values were observed under FI-N1 (911.1 kg ha- of N) than under DI-N0 (823.0 $\mathrm{kg} \mathrm{ha}^{-1}$ of $\mathrm{N})$, these differences were too low to render the treatments statistically different. However, there were significant differences $(\mathrm{P}<0.05)$ between treatments in terms of $\mathrm{N}$ surpluses (NS) in the soil at harvest. For instance, NS were higher under DI-N1. Under DI-N1, the lack of water inhibited the $\mathrm{N}$ from dissolving and, therefore, diminished the $\mathrm{N}$ uptake by the plant (as reported in Table 3 for DI-N1 and N0). On the contrary, treatments with higher irrigation and lower $\mathrm{N}$ fertilization (FI-N0) had a minor effect on $\mathrm{N}$ surpluses in the soil at harvest $\left(30.1 \mathrm{~kg} \mathrm{ha}^{-1}\right.$ of $\left.\mathrm{N}\right)$. The analysis of the main factor effect showed significant differences $(\mathrm{P}<0.05)$ among $\mathrm{N}$ fertilization rates, with NS of 125.0 and $38.6 \mathrm{~kg} \mathrm{ha}^{-1}$ of $\mathrm{N}$ under $\mathrm{N} 1$ and N0, respectively. However, no differences were reported when irrigation was the main factor. For the P mass balance (PB), there were no significant differences either between the main factors or amongst treatments. The results showed that when $\mathrm{N}$ fertilizer was the main factor, $\mathrm{PB}$ was higher under N0 (Table 5). On the contrary, higher PB values were reported under FI. As P uptake was similar among treatments, $\mathrm{P}$ surpluses at harvest showed no significant differences.
Furthermore, the differences between total N, P and K mass balance estimations and actual values at harvest were calculated using the MAPE (Eq. 10, Figure 3). The MAPE showed that estimated NB underestimated actual N values $(-7.5 \%)$; whereas the $\mathrm{PB}$ and $\mathrm{KB}$ were slightly overestimating actual values $(+4.3$ and $+3.3 \%$, respectively). Nevertheless, these differences between observed and estimated values were generally low, implying that mass balance equations for $\mathrm{N}, \mathrm{P}$ and $\mathrm{K}$ performed well.

\section{Discussion}

The sections of this study on macronutrient requirements and mass balances were crucial to better understand the needs of quinoa under a tropical savannah (wet and hot) climate and to minimize N, P, K losses into the environment.

The first objective of this study was to fill the gap in literature by examining macronutrient requirements of different parts of the plant. Our research reported an average of 2.08 and $1.63 \%$ of $\mathrm{N}$ and $\mathrm{K}$ in seeds, respectively; hence corroborating the results of Gómez-Ramírez et al. (2017) who reported similar concentrations

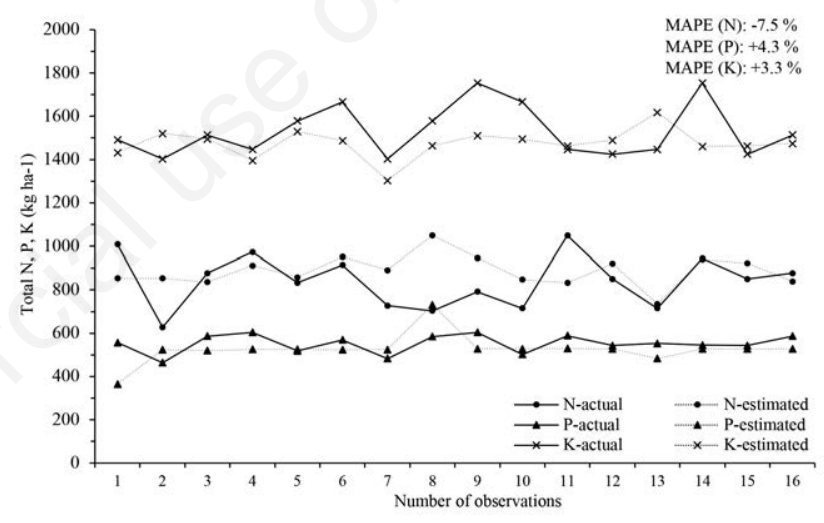

Figure 3. Differences (using MAPE) between observed N, P and $\mathrm{K}\left(\mathrm{kg} \mathrm{ha}^{-1}\right)$ soil content at harvest and estimated values from $\mathrm{N}$, $\mathrm{P}$ and $\mathrm{K}$ mass balance equations (NB, PB, KB).

Table 5. ANOVA and Tukey HSD test for N, P, K mass balances and N, P, K surpluses in the soil for different irrigation schedules (100 and $50 \%$ ETc) and $\mathrm{N}$ fertilization levels $\left(100\right.$ and $0 \mathrm{~kg} \mathrm{ha}^{-1}$ of $\left.\mathrm{N}\right)$. While $\mathrm{N}$ values refer to the concentration in the soil, $\mathrm{P}$ and $\mathrm{K}$ refer to its availability in the soil.

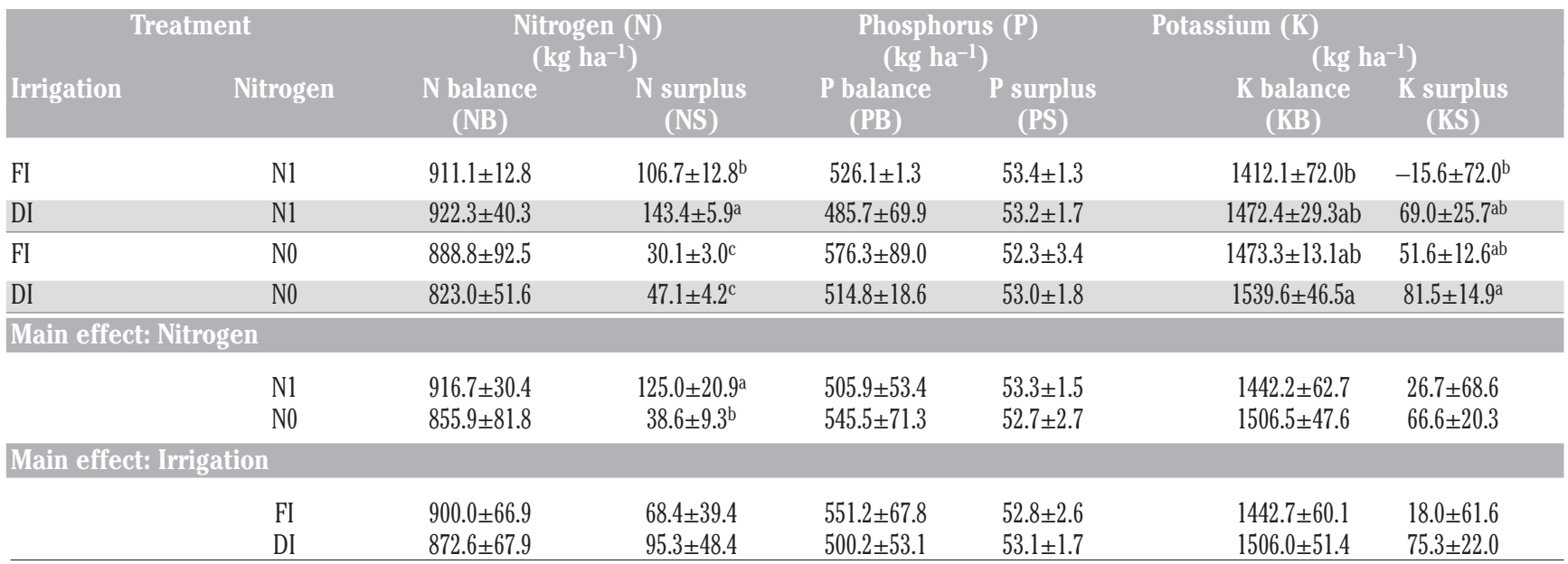

${ }^{\mathrm{a}-\mathrm{c} M e a n s}$ that do not share a letter were significant different at 5\% probability level using the Tukey HSD post-hoc test. 
( 2.36 and $1.79 \%$ of $\mathrm{N}$ and $\mathrm{K}$ content in seeds, respectively) in treatments subjected to low pressure radiofrequency plasma-LPRF (RF $10 \mathrm{~s})$. In addition, the average $\mathrm{N}$ seed content measured in our research $(2.08 \%)$ was slightly lower to that measured by Kakabouki et al. (2018), ranging from 2.6-2.8\%. In respects to K and $\mathrm{P}$ seed content, our work measured $16352 \mathrm{mg} \mathrm{kg}^{-1}$ of $\mathrm{K}$ and $2845 \mathrm{mg} \mathrm{kg}^{-1}$ of $\mathrm{P}$ (equivalent to $1.63 \% \mathrm{~K}$ and $0.28 \% \mathrm{P}$, average of all treatments). The latter were in harmony to those reported in literature, with a $\mathrm{P}$ concentration in quinoa seeds of $0.22 \%$ (Blanco, 2016). In comparison with other crops, the $\mathrm{K}$ content in seeds were in line to those observed in soybean $\left(15,800 \mathrm{mg} \mathrm{kg}^{-1}\right.$ of $\mathrm{K}$ ) (Parvej, 2015); but differed, were higher for $\mathrm{K}\left(16,352 \mathrm{mg} \mathrm{kg}^{-1}\right.$ of $\left.\mathrm{K}\right)$ and lower for $\mathrm{P}$ ( $2845 \mathrm{mg} \mathrm{kg}^{-1}$ of $\left.\mathrm{P}\right)$, to those observed in quinoa by Fuentes and Paredes-González (2015), reporting $5630 \mathrm{mg} \mathrm{kg}^{-1}$ of $\mathrm{K}$ and $4570 \mathrm{mg} \mathrm{kg}^{-1}$ of $\mathrm{P}$. These differences on $\mathrm{P}$ concentrations were explained by a downregulation of phosphorylated protein in crops exposed to water deficits, as reported by Luo et al. (2018) for maize. It was likely that phosphorylated protein played a key role on regulating the photosystem and metabolism of plants (Cheng et al., 2014). Other studies suggested similar responses on quinoa, where the phosphorylated protein modified key physiological processes such as photosynthesis, respiration, and water relations, among others (Zurita-Silva, 2015). Other authors affirm that protein and lipid (in the form of phospholipids) content in cv. Titicaca was higher after the abrasion of the pericarp, particularly of the linoleic omega fatty acid (Troisi et al., 2015). All of these possible physiological responses support the differences on $\mathrm{P}$ concentrations between our study and those conducted under different agroclimatic conditions.

The second main objective of this study on N, P, K mass balances and its responses to the combined effect of irrigation and fertilizer application was successfully addressed and the gap in literature fulfilled. Regarding N, P, K uptake and mass balances, we observed that irrigation was the main factor determining seed yield and biomass at harvest. Increasing $\mathrm{N}$ fertilization had a minimal effect on seed yields and dry biomass. This was observed when comparing different $\mathrm{N}$ fertilization rates; for instance, DI-N1 and DI-N0 (297 and $255 \mathrm{~kg} \mathrm{ha}^{-1}$ of seed, respectively). Various studies suggest that the low effectiveness of $\mathrm{N}$ fertilization in maize was due to a nutrient imbalance caused by the application of high rates of $\mathrm{P}$ and $\mathrm{K}$ (Adediran and Banjoko, 1995). Hence, the high $\mathrm{PO}_{4}{ }^{3-}$ application rates of this study, from BPR and compost, might have resulted in a nutrient imbalance and consequently the vain effect of $\mathrm{N}$ on crop growth and development. Another reason supporting the low effect of $\mathrm{N}$ on yields at harvest was the competition between bacterial community and the crop for $\mathrm{N}$ in the soil, thus reducing the efficiency of increasing $\mathrm{N}$ fertilization rates (N1). The previous statement supports the idea that quinoa yields did not significantly increase with higher $\mathrm{N}$ fertilization rates, unlike other experiments (Jacobsen et al., 1994; Kaul et al., 2005).

Thirdly, sustainable farming systems in SSA are now better understood for this crop thanks to a comprehensive evaluation of surpluses from fertilizer application. The N, P, K applications, in the form of $\mathrm{CO}\left(\mathrm{NH}_{2}\right)_{2}$, compost and $\mathrm{BPR}$, were higher to those required by quinoa and consequently in the results of mass balances and macronutrient surpluses found in the soil. In particular, $\mathrm{N}$ and $\mathrm{P}$, and to a lesser extent $\mathrm{K}$, received higher macronutrient inputs to those required by quinoa (surpluses of 81.8, 53.0 and 46.0 $\mathrm{kg} \mathrm{ha}{ }^{-1}$ of $\mathrm{N}, \mathrm{P}, \mathrm{K}$, respectively, average of all treatments). Additionally, in all treatments, similar N, P, K uptake values (20.4, 2.8 and $16.0 \mathrm{~kg} \mathrm{~N}, \mathrm{P}, \mathrm{K}$ per ton of seed produced, respectively) were observed to those reported in literature (18.7, 5.0 and $13.8 \mathrm{~kg}$ $\mathrm{N}, \mathrm{P}, \mathrm{K}$ per ton of seed produced, respectively) under optimal growing conditions in The Netherlands and Denmark (Moreale, 1993). While the present study measured 7.6, 0.8 and $42.9 \mathrm{~kg} \mathrm{~N}, \mathrm{P}$, K per ton of stems and leaves produced, Moreale's (1993) study recorded 5.0, 1.8 and $32.5 \mathrm{~kg} \mathrm{~N}, \mathrm{P}, \mathrm{K}$ per ton of stems and leaves produced. Regarding the $\mathrm{N}, \mathrm{P}$ and $\mathrm{K}$ requirements per ton of total biomass, including seeds, stems and leaves, few differences were depicted between these two studies; particularly, under optimal irrigation and $\mathrm{N}$ fertilization conditions. For instance, under FI-N1, an agreement was observed between our study and Moreale's (1993) in terms of N, P and K requirements, respectively with 25.3 and $23.8 \mathrm{~kg} \mathrm{ha}^{-1}$ of $\mathrm{N}, 3.1$ and $6.8 \mathrm{~kg} \mathrm{ha}^{-1}$ of $\mathrm{P}, 66.7$ and $46.3 \mathrm{~kg}$ $\mathrm{ha}^{-1}$ of $\mathrm{K}$ for one ton of total biomass produced. However, the present findings on $\mathrm{P}$ requirements $\left(3.1 \mathrm{~kg} \mathrm{ha}^{-1}\right.$ of $\mathrm{P}$ per one ton of total biomass) were slightly lower to those $\left(120 \mathrm{~kg} \mathrm{ha}^{-1}\right.$ of $\left.\mathrm{P}_{2} \mathrm{O}_{5}\right)$ cited in literature for a production of 4.0-7.0 ton ha ${ }^{-1}$ (equivalent to 4.8-8.4 $\mathrm{kg} \mathrm{ha}^{-1}$ of P per one ton of total biomass) (Mujica, 2015). Others (Sephar and Rocha, 2010) suggest a P application rate of 80 $\mathrm{kg} \mathrm{ha}^{-1}$ of $\mathrm{P}_{2} \mathrm{O}_{5}$ for seed yields over 2.0 ton $\mathrm{ha}^{-1}$ (equivalent to 10.8 $\mathrm{kg} \mathrm{ha}^{-1}$ of $\mathrm{P}$ per ton of seeds produced). In contrast, the present showed that only $2.8 \mathrm{~kg}$ of $\mathrm{P}$ were required to produce one ton of seeds. Also, this study demonstrated that the most required macronutrient was $\mathrm{K}(35.5 \mathrm{~kg}$ of $\mathrm{K}$ per one ton of total biomass produced, average of all treatments), with very similar $\mathrm{K}$ application rates observed by González et al. (2015) and Spehar et al. (2015) (100 kg of $\mathrm{K}_{2} \mathrm{O}$ for yields over 2.0 ton ha ${ }^{-1}$, equivalent to $41.5 \mathrm{~kg}$ of $\mathrm{K}$ per one ton of total biomass produced). Finally, the emerging findings support the sustainable management of quinoa in other regions with similar agroclimatic conditions, e.g. Mediterranean region, where quinoa is rapidly expanding (Pulvento et al., 2010; De Santis et al., 2016, 2018; Alvar-Beltrán et al., 2020).

\section{Conclusions}

The N, P, K mass balances of quinoa were useful for determining both the input requirements and outputs from crop removal and losses. Overall, the $\mathrm{N}$ and $\mathrm{K}$ requirements of quinoa were moderate to high ( 35.5 and $12.7 \mathrm{~kg}$ of $\mathrm{K}$ and $\mathrm{N}$ per one ton of total biomass produced, average of all treatments). The N, P and K mass balances were positive, notably for $\mathrm{N}$ and $\mathrm{P}$, and to a minor extent for $\mathrm{K}$. This confirmed that crop N, P, K requirements were lower to those estimated during the experimental design. For this reason, macronutrient surpluses were found in the field at harvest. For the optimal observed yields (1380 $\mathrm{kg} \mathrm{ha}^{-1}$ under FI-N1, with a fertilization of $56.1 \mathrm{~kg} \mathrm{ha}^{-1}$ of $\mathrm{P}$ and $111.7 \mathrm{~kg} \mathrm{ha}^{-1}$ of $\mathrm{K}$ in the form of compost and BPR), the $\mathrm{N}$ and $\mathrm{P}$ surpluses were considerably high at $106.7 \mathrm{~kg} \mathrm{ha}^{-1}$ of $\mathrm{N}$ and $53.4 \mathrm{~kg} \mathrm{ha}^{-1}$ of $\mathrm{P}$, respectively, but low for $\mathrm{K}\left(-15.6 \mathrm{~kg} \mathrm{ha}^{-1}\right.$ of $\left.\mathrm{K}\right)$. In order to attain the highest yields while maintaining nutrient balance, the present results indicate that $\mathrm{P}$ needs to be applied at lower rates, and therefore $5000 \mathrm{~kg} \mathrm{ha}^{-1}$ of compost (10 kg ha- $\mathrm{kf}^{-1}$ ) should suffice quinoa's $\mathrm{P}$ demand. Hence, it is not necessary to provide additional $\mathrm{P}$ in the form of phosphate (BPR). Also, reducing $\mathrm{P}$ fertilization rates could be beneficial in terms of yield besides of increasing $\mathrm{N}$ efficacy. In this experiment, $5000 \mathrm{~kg} \mathrm{ha}^{-1}$ of compost provided the field with $111.7 \mathrm{~kg} \mathrm{ha}^{-1}$ of $\mathrm{K}$, which was lower to that required by the crop under optimal growing conditions, FI-N1 $\left(-15.6 \mathrm{~kg} \mathrm{ha}^{-1}\right.$ of $\left.\mathrm{K}\right)$. A recommendation for providing the field with the necessary macronutrients is to fertilize with chemical compounds that have higher concentration of $\mathrm{K}$ and $\mathrm{N}$, e.g. potassium nitrate $\left(\mathrm{KNO}_{3}\right)$ with $13 \% \mathrm{~N}$ and $37 \%$ $\mathrm{K}$, respectively. Combined fertilizers can be cost-effective and 
approximately $400 \mathrm{~kg}$ of $\mathrm{KNO}_{3}$ are sufficient for satisfying quinoa's $\mathrm{N}$ and $\mathrm{K}$ requirements for producing one ton of total biomass (including seeds, stems and leaves). Considering the typical sandy-loam texture of the experimental field, the use of organic matter can be promoted for increasing the water holding capacity of the soil. Overall, agronomic efficiency through fertilizer management practices, including those related with planting density, time of sowing, weeding, split of fertilizer and application rates need to be further explored. We then therefore expect higher yields besides minimizing the environmental costs associated with fertilizer misuse in SSA.

\section{References}

Adediran JA, BanjokoVA, 1995. Response of maize to nitrogen, phosphorus, and potassium fertilizers in the savanna zones of Nigeria. Commun. Soil Sci. Plant Anal. 26:593-606.

Allen RG, Pereira LS, Raes D, Smith M, 1998. In Crop Evapotranspiration-Guidelines for computing crop water requirements. FAO Irrigation and drainage paper 56, 300(9), D05109. FAO, Rome, Italy.

Alvar-Beltrán J, Dao A, Saturnin C, Dalla Marta A, Sanou J, Orlandini S, 2019. Effect of drought, nitrogen fertilization, temperature, and photoperiodicity on quinoa plant growth and development in the Sahel. Agron. J. 9:607.

Alvar-Beltrán J, Fabbri C, Verdi L, Truschi S, Dalla Marta A, Orlandini S, 2020. Testing proximal optical sensors on Quinoa growth and development. Remote Sensing 12:1958.

Blanco J-A, 2016. Chapter 3.2. Fodder and animal feed. In: D. Bazile, H.D. Bertero, C. Nieto (Eds.), State of the art report on quinoa around the world in 2013. FAO, CIRAD, Santiago de Chile, pp. 250-266.

Cheng H, Deng W, Wang Y, Ren J, Liu Z, Xue Y, 2014. dbPPT: a comprehensive database of protein phosphorylation in plants. Database, 2014. Available from: https://academic.oup.com/ database/article/doi/10.1093/database/bau121/2635578?login $=$ true

Dao A, Alvar-Beltrán J, Gnanda A, Guira A, Nebie L, Sanou J, 2020. Effect of different planting techniques and sowing density rates on the development of quinoa. Afr. J. Agric. Res. 16:1325-33.

Delon C, Galy-Lacaux C, Boone A, Liousse C, Serça D, Adon M, Timouk F, 2010. Atmospheric nitrogen budget in Sahelian dry savannas. Atmos. Chem. Physics 10:2691-708.

De Santis G, Maddaluno C, D’Ambrosio T, Rascio A, Rinaldi M, Troisi J, 2016. Characterisation of quinoa (Chenopodium quinoa Willd.) accessions for the saponin content in Mediterranean environment. Ital. J. Agron. 11:277-81.

De Santis G, Ronga D, Caradonia F, D’Ambrosio T, Troisi J, Rascio A, Fragasso MG, Pecchioni N, Rinaldi M, 2018. Evaluation of two groups of quinoa (Chenopodium quinoa Willd.) accessions with different seed colours for adaptation to the Mediterranean environment. Crop Pasture Sci. 69:1264-75.

Eickhout B, Bouwman AV, Van Zeijts H, 2006. The role of nitrogen in world food production and environmental sustainability. Agric. Ecosyst. Environ. 116:4-14.

Erisman JW, Sutton MA, Galloway J, Klimont Z, Winiwarter W, 2008. How a century of ammonia synthesis changed the world. Nature Geosci. 1:636.

FAO (Food and Agricultural Organization), 2011. Grow: a policymakers' guide to the sustainable intensification of smallholder crop production. Food and Agriculture Organization of the United Nations, Rome, Italy.

Fuentes F, Paredes-González, 2015. In state of the art report of quinoa in the world in 2013. Chapter 3.5: Nutraceutical perspectives of quinoa: biological properties and functional applications. FAO and CIRAD, Rome, Italy, pp. 286-299.

Gebrelibanos G, Dereje A, 2015. Nitrogen fertilization effect on grain sorghum (Sorghum bicolor L. Moench) yield, yield components and witchweed (Striga hermonthica (Del.) Benth) infestation in Northern Ethiopia. Int. J. Agric. Res. 10:14-23.

Gómez-Ramírez A, López-Santos C, Cantos M, García JL, Molina R, Cotrino J, González-Elipe AR, 2017. Surface chemistry and germination improvement of Quinoa seeds subjected to plasma activation. Sci. Rep. 7:1-12.

González JA, Eisa S, Hussin SAES, Prado FE, 2015. Quinoa: an Incan crop to face global changes in agriculture. Quinoa Improv. Sustain. Prod. 1-18.

Hargreaves GH, Samani ZA, 1985. Reference crop evapotranspiration from temperature. Appl. Engine. Agric. 1:96-9.

IPNI (International Plant Nutrition Institute), 2019. Nitrogen notes: managing urea, number 2. [Online-Report] [accessed on 13 December 2019]. Available from: http://www.ipni.net/NitrogenNotes

Jacobsen SE, Jørgensen I, Stølen O, 1994. Cultivation of quinoa (Chenopodium quinoa) under temperate climatic conditions in Denmark. J. Agric. Sci. 122:47-52.

Kakabouki IP, Hela D, Roussis I, Papastylianou P, Sestras AF, Bilalis DJ, 2018. Influence of fertilization and soil tillage on nitrogen uptake and utilization efficiency of quinoa crop (Chenopodium quinoa Willd.). J. Soil Sci. Plant Nutr. 18:220-35.

Kaul HP, Kruse M, Aufhammer W, 2005. Yield and nitrogen utilization efficiency of the pseudocereals amaranth, quinoa, and buckwheat under differing nitrogen fertilization. Eur. J. Agron. 22:95-100.

Luo F, Deng X, Liu Y, Yan Y, 2018. Identification of phosphorylation proteins in response to water deficit during wheat flag leaf and grain development. Botan. Studies 59:28.

Moreale A, 1993. In The quinoa project: Wageningen University. Available from: http://edepot.wur.nl/354101 Accessed: 03/12/2019.

Mujica A, 2015. In state of the art report of quinoa in the world in 2013. Chapter 5.2: Peru. FAO and CIRAD, Rome, Italy, pp. 378-387.

Parvej M, Slaton NA, Purcell LC, Roberts TL, 2015. Potassium fertility effects yield components and seed potassium concentration of determinate and indeterminate soybean. Agron. J. 107:943-50.

Pulvento C, Riccardi M, Lavini A, d'Andria R, Iafelice G, Marconi E, 2010. Field trial evaluation of two chenopodium quinoa genotypes grown under rain $\square$ fed conditions in a typical Mediterranean environment in South Italy. J. Agron. Crop Sci. 196:407-11.

Robertson GP, Vitousek PM, 2009. Nitrogen in agriculture: balancing the cost of an essential resource. Annu. Rev. Environ. Resour. 34:97-125.

Sheaffer CC, Moncada KM, 2012. Introduction to agronomy: food, crops, and environment. Cengage Learning, Boston, MA, USA.

Spehar CR, da Silva Rocha JE, 2010. Exploiting genotypic variability from low-altitude Brazilian Savannah-adapted Chenopodium quinoa. Euphytica 175:13-21.

Spehar C, Silva-Rocha J, Ribeiro W, de Barros Santos R, Ascheri J, Jesus Souza F, 2015. Chapter 6.4.2. Advances and chal- 
lenges for quinoa production and utilization in Brazil. In: D. Bazile, H.D. Bertero, C. Nieto (Eds.), State of the art report on quinoa around the world in 2013. FAO, CIRAD, Santiago de Chile, pp. 562-583.

Troisi J, Di Fiore R, Pulvento C, D’Andria R, Vega-Gálvez A, Miranda M, Martínez E, Lavini A. 2015. Chapter 3.3: Saponins. In: D. Bazile, H.D. Bertero, C. Nieto (Eds.), State of the art report on quinoa around the world in 2013. FAO, CIRAD, Santiago de Chile, pp. 267-277.

USDA (United States Department of Agriculture), 2013. USDA National Nutrient Database for Standard Reference, Release 26. Nutrient Data Laboratory Home. [Online-Report]. Available from: https://www.ars.usda.gov/ Accessed:11 November 2019.

USEPA (United States Environmental Protection Agency), 2004. National emission inventory - Ammonia emissions from ani- mal husbandry operations. USEPA, Washington, DC, USA. Vanlauwe B, Wendt J, Giller KE, Corbeels M, Gerard B, Nolte C, 2014. A fourth principle is required to define conservation agriculture in sub-Saharan Africa: the appropriate use of fertilizer to enhance crop productivity. Field Crop. Res. 155:10-3.

Zingore S, Njoroge S, Chikowo R, Kihara J, Nziguheba G, Nyamangara J, 2014. Plant nutrient management in African agriculture: an extension handbook for fertilizer management in smallholder farming systems. [Online-Report]. Available from: http://ssa.ipni.net/ipniweb/region/africa.nsf Accessed: 25 November 2019.

Zurita-Silva A, 2015. Chapter 2.4: Quinoa drought responses and adaptation. In: D. Bazile, H.D. Bertero, C. Nieto (Eds.), State of the art report on quinoa around the world in 2013. FAO, CIRAD, Santiago de Chile, pp. 157-171. 